\title{
HOST DETERMINANT BASED PREVALENCE OF TICKS AND LICE IN CATTLE (BOS INDICUS) AT BOGRA DISTRICT OF BANGLADESH
}

\author{
M. F. Bilkis, M. M. H. Mondal, Sa. Rony*, M. A. Islam ${ }^{1}$ and N. Begum \\ Department of Parasitology, Bangladesh Agricultural University \\ Mymensingh-2202, Bangladesh
}

\begin{abstract}
A cross section survey was carried out during the period from April to September, 2009 in different villages of Bogra district in Bangladesh to know the prevalence of ticks and lice in relation to age, sex, breed and body condition of cattle. Out of 250 randomly selected cattle, $142(56.8 \%)$ were found infested with one or more species of ticks and lice. Among ticks, the prevalence rate was highest in case of Haemaphysalis bispinosa (31.2\%) followed by Rhipicephalus sanguineus $(29.2 \%)$, Boophilus microplus $(27.2 \%)$ and only one species of louse Haematopinus eurysternus (23.2\%). The range of parasitic burden was 1 to 16 per four square inch of heavily infested area of affected cattle. Mean parasitic burden was high in case of Haematopinus eurysternus (4.71 \pm 0.35) followed by Rhipicephalus sanguineus (4.56 \pm 0.29$)$, Boophilus microplus (4.25 \pm 0.15$)$ and Haemaphyalis bispinosa $(2.85 \pm 0.17)$. Results indicated that prevalence was significantly $(\mathrm{P}<0.01)$ higher in young cattle aged $>1-3$ years $(68.0 \%)$ than calves aged $\leq 1$ year age $(46.15 \%)$ and adults aged $>3$ years $(45.2 \%)$. Infestation of tick and lice was significantly higher $(\mathrm{P}<0.05)$ in female $(64.63 \%)$ than the male $(41.86 \%)$. Infestation was more prevalent in local $(72.32 \%)$ breed than the crossbred $(44.2 \%)$ cattle. Cattle with poor body condition were found to be significantly $(\mathrm{P}<0.01)$ more vulnerable to such parasitic infestation than of cattle having normal body condition. It is concluded that tick and lice prevalence is alarming and threatening to the cattle population and host determinants play a vital role in the frequent occurrence of these ectoparasites in the study area.
\end{abstract}

Key Words: Cattle, Tick, Lice, Prevalence

\section{INTRODUCTION}

Livestock plays a significant role in the agricultural economy of Bangladesh. There are about 24.9 million cattle in Bangladesh (BERi, 2008). Cattle are the main source of animal protein as they provide meat, milk and source of draft power and hides. From cattle, Bangladesh gets 173 thousand metric tons beef and 782 thousands metric tons milk per year. Further, the country gets 18 thousand metric tons butter and ghee and 32 thousand

\footnotetext{
${ }^{1}$ Department of Medicine, Bangladesh Agricultural University, Mymensingh-2202, Bangladesh

i Bangladesh Economic Review

*Corresponding author:- E-mail: saronydvm@gmail.com; Cell: +8801719-217898
} 
metric tons excellent type of hides from cattle (BBSii, 2001). Bangladesh earns 2.09\% foreign money by exporting leather and leather goods (DLSiii, 2001). But cattle rearing is hindered by various problem among them malnutrition and parasitic infestation are the major limiting factors especially in Bangladesh (Jabbar and Green, 1983) since the climate condition of Bangladesh is very conducive to a wide variety of ecto and endoparasites.

Different species of ticks and lice are widely distributed in Bangladesh and a number of researchers reported the distribution and abundance of tick species in different parts of the country (Rony et al., 2010). They have a major effect on the husbandry and productivity of livestock, weight gain (Gibney et al., 1985), milk production and quality of hide (Coles et al., 2003). When present at high intensities, ticks and lice may cause harm indirectly, such as nuisance, reduced time spent for grazing or ruminating, rubbing and self-wounding (Weeks et al., 1995) and cause direct damage to skin and other sub-cutaneous tissues such as pruritus, alopecia and excoriation (Wall and Shearer, 1997). Moreover, ticks and lice act as vectors of viruses, rickettsia, bacteria, protozoa, cestodes and nematodes, including vectors of zoonotic diseases in humans (Petney et al., 2007).

In developed countries, the data on epidemiology of various ectoparasites are published in an efficient manner as an aid to combat infestations more efficiently. In contrast, in Bangladesh so far little published information exists on the epidemiological aspects of such infestation. Epidemiological pattern of these parasites in different agro-climatic zones of the country would provide a basis to evolving strategic and tactical control of vectorborne diseases. Therefore, the present research was undertaken to investigate tick and lice fauna in the study area and to study the effects of host-associated factors like age, sex, breed and body condition on their prevalence.

\section{MATERIALS AND METHODS}

\section{Ethical issue}

Before sampling, informed consent was obtained from the animal owners participating in the study and cautions were taken to ensure minimum stress to the animal during sampling.

\section{Experimental settings}

The present study was a cross sectional survey based on stratified random sampling. Two hundred and fifty cattle were randomly selected from households of selected villages of Kahalo upazila in Bogra, Bangladesh. All selected cattle were subjected to thorough physical examination to check the infestation with tick and lice. The whole study was conducted over the period from April to September, 2009.

\footnotetext{
iiBangladesh Bureau of Statistics, iiiDepartment of Livestock Services
} 


\section{Collection of animal level data}

Information on host determinants viz. age, sex, breed and body condition and other relevant data were collected by a semi structured questionnaire with interviewing farmers. Age of cattle was determined by asking the attendant or by dentition where possible and categorized animals based on age as calf ( $\leq 1$ year), young ( $>1-3$ year) and adult ( $>3$ year). Breeds of cattle were determined by origin and physical characteristics of respective breeds. Body conditions or relative fatness of selected cattle were judged by visual observation of skeletal structure and muscular covering of body. Cattle with bony prominence on tubercoxae, spine of vertebra visible ribs, depressed flank and sunken perianal fold considered as poor body condition and normal otherwise.

\section{Collection and preservation of samples}

After proper restraining, cattle were examined by close inspection, palpation and parting the hairs against their natural direction for easy observation of ticks and lice. Tick and lice were collected from different body parts of cattle by hand picking and by using tools. Ectoparasites encountered either on the skin surface or attached to the hair were also sampled. When required, small hair brush dipped in ethanol was used. Multiple sites were investigated to increase the likelihood of ectoparasite detection. Ticks and lice were preserved in labeled, clear, well-stopped glass vials with $70 \%$ alcohol and transport to the laboratory for morphological study.

\section{Identification of ticks and lice}

Morphological examination of ticks and lice was conducted in the department of Parasitology, Bangladesh Agricultural University, Mymensingh with the help of dissecting (4X) and compound (10X) microscope according to the keys and descriptions given by Wall and Shearer (1997) and Soulsby (1982). The preparation of permanent slides followed the procedures described by Cable (1967).

\section{Statistical analysis}

Statistical analyses were carried out by using Statistical Package for Social Sciences (SPSS) using $\mathrm{F}$ test. Odds ratio was calculated according to the formula given by Schlesselman (1982). The p-value of $\leq 0.05$ was considered as significant for all cases.

\section{RESULTS AND DISCUSSIONS}

\section{Overall prevalence}

Out of 250 randomly selected cattle, $142(56.8 \%)$ were found infested with one or more species of ticks and lice. Among ticks, the prevalence rate was highest in case of Haemaphysalis bispinosa (31.2\%) followed by Rhipicephalus sanguineus (29.2\%) Boophilus microplus $(27.2 \%)$ whereas louse infestation with Haematopinus eurysternus was $23.2 \%$. The range of parasitic burden was 1 to 16 per four square inch of heavily infested area of 
affected cattle. Mean parasitic burden was high in case of Haematopinus eurysternus (4.71 \pm 0.35 ) followed by Rhipicephalus sanguineus (4.56 \pm 0.29$)$, Boophilus microplus ( $4.25 \pm 0.15)$ and Haemaphyalis bispinosa $(2.85 \pm 0.17)$. The main attachment sites of lice were tail, ventral abdomen, ear, neck while that of ticks were ear, base of the horn, neck face, ventral abdomen, mammary gland, udder, and dewlap neck.

The result of current study is comparable with the previous report of several authors. An overall prevalence of ectoparasite as $64.07 \%$ in cattle with Boophilus microplus (45.63\%) Rhipicephalus sanguineus (36.89) in Gazipur district of Bangladesh was reported by Rony et al. (2010). Although a higher prevalence $(80 \%)$ of ectoparasitic infestation reported by Ghosh et al. (2007). Islam et al. (2006) reported B. microplus (42.4\%), H. bispinosa (12.0\%) and $R$. sanguineus $(10.8 \%)$ in cattle in Bangladesh. The finding of such a high prevalence of external parasites in the current study area might have been attributed to poor handling, lack of awareness about the effect of external parasites on cattle and to a greater extent lack of access to control schemes. In term of lice infestations, only Haematopinus eurysternus was recorded $23.2 \%$ in cattle in the study area. The finding of louse infestation might be indicative of some other underlying problems such as malnutrition and chronic diseases (Radostits et al., 2007).

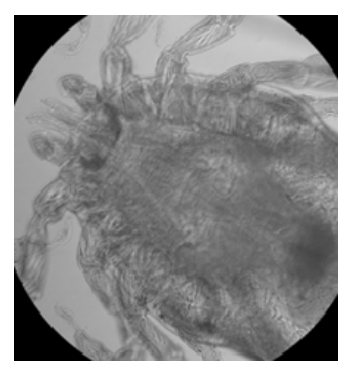

(a)

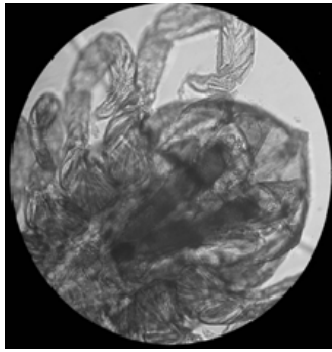

(b)

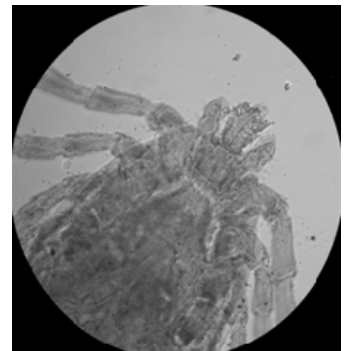

(a)

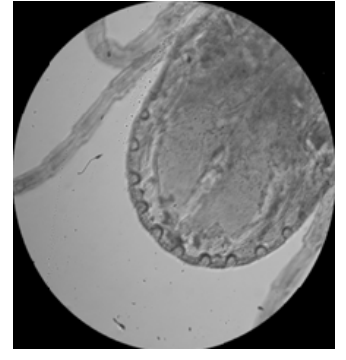

(b)

Fig. 1. Mouth part (a) and Posterior part (b) of Boophilus microplus

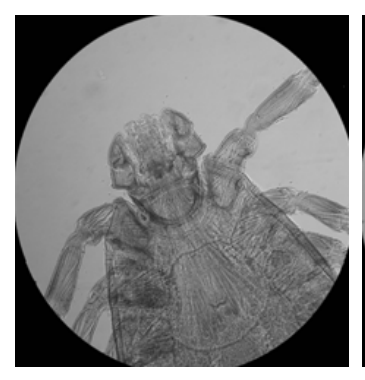

(a)

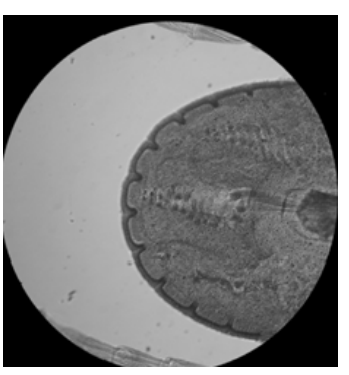

(b)

Fig. 2. Mouth part (a) and Posterior part (b) of Rhipicephalus sanguineus

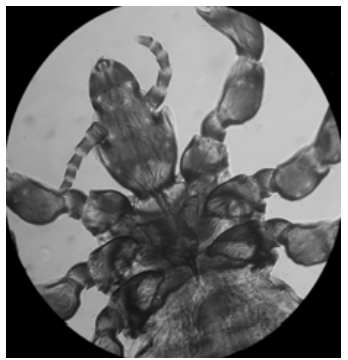

(a)

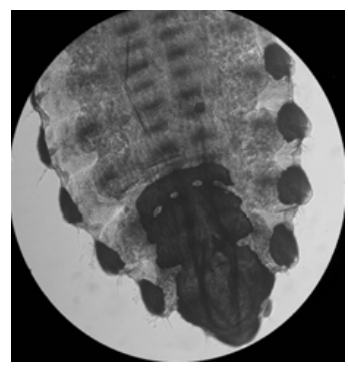

(b)

Fig. 3. Mouth part (a) and Posterior part (b) of Haemaphysalis bispinosa

Fig. 4. Mouth part (a) and Posterior part (b) of Haematopinus eurysternus 


\section{Prevalence related to age of cattle}

Prevalence was significantly $(\mathrm{P}<0.01)$ higher in cattle aged between 1 and 3 years $(68.0 \%)$ than calves aged $\leq 1$ year age $(46.15 \%)$ and adults aged $>3$ years $(45.2 \%)$ (Table 1$)$. Young were 2.48 and 2.58 times more susceptible to ticks and lice infestation than calves and adults, respectively. But calves and adult animals were almost equally susceptible (odds ratio $=1.04)$ to ectoparasitic infestation. Swai et al. (2005) found mature animals having higher prevalence of ticks $(\mathrm{P}=0.018)$ than young stock in Tanzania. On the contrary, cattle and buffaloes up to 1 year of age had a higher degree of ectoparasite infestation than the animals aged over 2 years (Sanjay and Prasad, 2004). The prevalence of lice was less in adult cattle compare to young reported in England (Milnes and Green, 1999). It is generally observed that younger animals are more susceptible to parasite infestation compared to adults. It is very difficult to explain exactly the reason behind the frequent occurrence of tick and lice infestation in young animals. But it may be assumed that the study period, health status, deworming, season and other management variables may have contributed to this result.

\section{Prevalence related to sex of cattle}

Infestation of tick and lice was significantly higher $(\mathrm{P}<0.05)$ in female $(64.63 \%)$ than the male $(41.86 \%)$ (Table 1). Female cattle were 2.54 times more susceptible to ticks and lice infestations than male. This result revealed that there was significant $(\mathrm{P}<0.05)$ disparity in harboring tick and lice between sex groups. The prevalence of Haematopinus sp. was higher $(29.22 \%)$ in female hosts compared to male hosts $(17.40 \%)$. It shows that the males have low prevalence for Haematopinus sp. which could be explained on the basis that the male hosts were more resistant to this louse. This study agrees with the findings of Rony et al. (2010) who reported significantly $(\mathrm{P}<0.05)$ higher prevalence in female $(69.74 \%)$ than male $(41.17 \%)$ animals. Although the exact cause of higher prevalence of such infestation in female cattle cannot be explained but it can be hypothesized that some hormonal influences may be associated with this phenomenon. Higher level of prolactin and progesterone hormones makes the female individual more susceptible to any infection (Lloyd, 1983). Etter et al. (1999) also found immune compromised animals acquiring higher tick infestation. Moreover, stresses of production such as pregnancy and lactation make the females more susceptible to such infestation.

\section{Prevalence related to breed of cattle}

Infestation was more prevalent in local $(72.32 \%)$ breed than the crossbred $(44.2 \%)$ cattle (Table 2). Local cattle were 3.3 times more susceptible to infestations than crossbred cattle. The mean parasitic burden was also higher in local breed $(3.54 \pm 0.36)$ than crossbreed (3.02 \pm 0.18$)$. Among crossbred cattle, Holstein-Friesian cross, Sindhi cross, Shahiwal cross were most commonly observed in the study area. Yacob et al. (2008) found a positive correlation between prevalence and production system and breed of cattle. Although the exact cause of higher prevalence of infestation in local cattle cannot be explained but it can be assumed that it may be associated with genetic and inheritable effects and lack of interest of the farmer about local cattle as well as taking more care to crossbred due to their high productivity than local cattle. 
Table 1. Age and sex related prevalence of ticks and lice in cattle of Bogra district in Bangladesh

\begin{tabular}{|c|c|c|c|c|c|c|c|}
\hline \multirow[t]{2}{*}{ Factor } & \multirow{2}{*}{$\begin{array}{c}\text { Category } \\
\text { level }\end{array}$} & \multirow{2}{*}{$\begin{array}{c}\text { Name of ticks } \\
\text { and lice } \\
\text { Recovered }\end{array}$} & \multirow{2}{*}{$\begin{array}{l}\text { No. of cattle } \\
\text { affected (\%) } \\
\text { N = 250 }\end{array}$} & \multicolumn{2}{|c|}{ Ticks and lice burden } & \multirow{2}{*}{$\begin{array}{l}\text { Odds } \\
\text { ratio }\end{array}$} & \multirow{2}{*}{$\begin{array}{l}\text { Signific- } \\
\text { ance } \\
\text { Level }\end{array}$} \\
\hline & & & & Range & Mean \pm SE & & \\
\hline \multirow{15}{*}{ Age } & \multirow{5}{*}{$\begin{array}{l}\text { Calf } \\
(\leq 1 \text { year }) \\
n=52\end{array}$} & B.microplus & $14(26.92 \%)$ & $1-3$ & $1.23 \pm 0.025$ & \multirow{5}{*}{$\begin{array}{c}\text { Young } \\
\text { vs } \\
\text { Calves } \\
=2.48\end{array}$} & \multirow{15}{*}{$P=0.0001$} \\
\hline & & R. sanguineus & $11(21.15 \%)$ & $1-6$ & $2.44 \pm 0.12$ & & \\
\hline & & H. bispinosa & $10(19.23 \%)$ & $1-6$ & $3.52 \pm 0.22$ & & \\
\hline & & H.eurysternus & $12(23.08 \%)$ & $1-13$ & $4.85 \pm 0.32$ & & \\
\hline & & Subtotal & $24^{*}(46.15 \%)$ & $1-13$ & $3.01 \pm 0.47$ & & \\
\hline & \multirow{5}{*}{$\begin{array}{l}\text { Young } \\
\text { (1-3 year) } \\
n=125\end{array}$} & B.microplus & $38(30.4 \%)$ & $1-10$ & $4.12 \pm 0.61$ & \multirow{5}{*}{$\begin{array}{c}\text { Young } \\
\text { vs } \\
\text { adults } \\
=2.58\end{array}$} & \\
\hline & & R. sanguineus & $45(36.0 \%)$ & $1-16$ & $3.95 \pm 0.39$ & & \\
\hline & & H. bispinosa & $49(39.2 \%)$ & $1-9$ & $5.04 \pm 0.71$ & & \\
\hline & & H.eurysternus & $35(28.0 \%)$ & $1-12$ & $3.18 \pm 0.49$ & & \\
\hline & & Subtotal & $85^{*}(68.0 \%)$ & $1-16$ & $4.07 \pm 0.51$ & & \\
\hline & \multirow{5}{*}{$\begin{array}{l}\text { Adult } \\
(>3 \text { year) } \\
n=73\end{array}$} & B.microplus & $16(21.92 \%)$ & $1-4$ & $2.36 \pm 0.41$ & \multirow{5}{*}{$\begin{array}{l}\text { Calves } \\
\text { vs } \\
\text { adults } \\
=1.04\end{array}$} & \\
\hline & & R. sanguineus & $17(23.29 \%)$ & $1-7$ & $2.41 \pm 0.22$ & & \\
\hline & & H. bispinosa & $19(26.03 \%)$ & $1-5$ & $2.15 \pm 0.15$ & & \\
\hline & & H.eurysternus & $11(15.07 \%)$ & $1-9$ & $1.25 \pm 0.03$ & & \\
\hline & & Subtotal & $33^{*}(45.2 \%)$ & $1-9$ & $2.04 \pm 0.27$ & & \\
\hline \multirow{10}{*}{ Sex } & & B.microplus & $16(18.6 \%)$ & $1-10$ & $2.25 \pm 0.42$ & \multirow{10}{*}{$\begin{array}{c}\text { Female } \\
\text { vs } \\
\text { Male } \\
=2.54\end{array}$} & \multirow{10}{*}{$P=0.023$} \\
\hline & & R. sanguineus & $19(22.09 \%)$ & $1-11$ & $3.50 \pm 0.53$ & & \\
\hline & & H. bispinosa & $20(23.25 \%)$ & $1-9$ & $2.00 \pm 0.12$ & & \\
\hline & & H.eurysternus & $15(17.44 \%)$ & $1-11$ & $2.54 \pm 0.23$ & & \\
\hline & & Subtotal & $36 *(41.86 \%)$ & $1-11$ & $2.57 \pm 0.46$ & & \\
\hline & \multirow{5}{*}{$\begin{array}{l}\text { Female } \\
\mathrm{n}=164\end{array}$} & B.microplus & $52(31.71 \%)$ & $1-8$ & $3.25 \pm 0.39$ & & \\
\hline & & R. sanguineus & $54(32.93 \%)$ & $1-16$ & $3.42 \pm 0.31$ & & \\
\hline & & H. bispinosa & $58(35.36 \%)$ & $1-7$ & $3.60 \pm 0.27$ & & \\
\hline & & H.eurysternus & $43(29.22 \%)$ & $1-13$ & $2.95 \pm 0.11$ & & \\
\hline & & Subtotal & $106^{*}(64.63 \%)$ & $1-16$ & $3.31 \pm 0.52$ & & \\
\hline
\end{tabular}

\section{Prevalence related to body condition of cattle}

Cattle with poor body condition were found to be significantly $(\mathrm{P}<0.01)$ more vulnerable to such parasitic infestation than of cattle having normal body condition (Table 2). Tick and lice infestation was recorded higher in poor body conditioned $(70.94 \%)$ cattle than in normal body condition $(36.27 \%$ ) cattle. Odds ratio implied that poor conditioned animals are 4.22 times more vulnerable to such infestation than animals with normal health condition. The present study agrees with the earlier study of Rony et al. (2010) who 
reported 2.88 times higher prevalence in exhausted cattle than normal healthy animals. From the observations of Manan et al. (2007) also indicated that bony conditioned animals are least resistant to tick infestation and lacking enough body potential to build resistance with age advancement whereas over-conditioned animals showed reasonable combat to the infestation.

Table 2. Prevalence of tick and lice related wit breed and body condition of cattle in Bogra district of Bangladesh

\begin{tabular}{|c|c|c|c|c|c|c|c|}
\hline \multirow[t]{2}{*}{ Factor } & \multirow{2}{*}{$\begin{array}{c}\text { Category } \\
\text { level }\end{array}$} & \multirow{2}{*}{$\begin{array}{c}\text { Name of ticks } \\
\text { and lice } \\
\text { Recovered }\end{array}$} & \multirow{2}{*}{$\begin{array}{l}\text { No. of cattle } \\
\text { affected (\%) } \\
\text { N = 250 }\end{array}$} & \multicolumn{2}{|c|}{ Ticks and lice burden } & \multirow{2}{*}{$\begin{array}{l}\text { Odds } \\
\text { ratio }\end{array}$} & \multirow{2}{*}{$\begin{array}{l}\text { Signific- } \\
\text { ance Level }\end{array}$} \\
\hline & & & & Range & Mean \pm SE & & \\
\hline \multirow{10}{*}{ Breed } & \multirow{5}{*}{$\begin{array}{l}\text { Local } \\
\mathrm{n}=112\end{array}$} & B.microplus & $39(34.82 \%)$ & $1-10$ & $3.25 \pm 0.34$ & \multirow{10}{*}{$\begin{array}{l}\text { Local } \\
\text { vs } \\
\text { Cross } \\
=3.3\end{array}$} & \multirow{10}{*}{$P=0.0023$} \\
\hline & & R. sanguineus & $43(38.39 \%)$ & $1-16$ & $4.12 \pm 0.28$ & & \\
\hline & & H. bispinosa & $45(40.18 \%)$ & $1-9$ & $3.82 \pm 0.42$ & & \\
\hline & & H.eurysternus & $35(31.25 \%)$ & $1-11$ & $2.95 \pm 0.31$ & & \\
\hline & & Subtotal & $81 *(72.32 \%)$ & $1-16$ & $3.54 \pm 0.36$ & & \\
\hline & \multirow{5}{*}{$\begin{array}{l}\text { Cross } \\
n=138\end{array}$} & B.microplus & $29(21.01 \%)$ & $1-8$ & $3.12 \pm 0.41$ & & \\
\hline & & R. sanguineus & $30(21.74 \%)$ & $1-11$ & $2.50 \pm 0.22$ & & \\
\hline & & H. bispinosa & $33(23.91 \%)$ & $1-7$ & $3.24 \pm 0.36$ & & \\
\hline & & H.eurysternus & $23(16.66 \%)$ & $1-13$ & $3.22 \pm 0.29$ & & \\
\hline & & Subtotal & $61 *(44.2 \%)$ & $1-13$ & $3.02 \pm 0.18$ & & \\
\hline \multirow{10}{*}{$\begin{array}{l}\text { Body } \\
\text { condition }\end{array}$} & \multirow{5}{*}{$\begin{array}{l}\text { Normal } \\
\mathrm{n}=102\end{array}$} & B.microplus & $14(13.72 \%)$ & $1-10$ & $3.12 \pm 0.39$ & \multirow{10}{*}{$\begin{array}{c}\text { Poor } \\
\text { vs } \\
\text { Normal } \\
=4.22\end{array}$} & \multirow{10}{*}{$P=0.0002$} \\
\hline & & R. sanguineus & $13(12.74 \%)$ & $1-11$ & $2.58 \pm 0.27$ & & \\
\hline & & H. bispinosa & $14(13.72 \%)$ & $1-9$ & $2.46 \pm 0.12$ & & \\
\hline & & H.eurysternus & $15(14.7 \%)$ & $1-12$ & $2.39 \pm 0.09$ & & \\
\hline & & Subtotal & $37 *(36.27 \%)$ & $1-12$ & $2.64 \pm 0.10$ & & \\
\hline & \multirow{5}{*}{$\begin{array}{l}\text { Poor } \\
n=148\end{array}$} & B.microplus & $54(36.49 \%)$ & $1-8$ & $3.42 \pm 0.21$ & & \\
\hline & & R. sanguineus & $60(40.58 \%)$ & $1-16$ & $4.12 \pm 0.54$ & & \\
\hline & & H. bispinosa & $64(43.24 \%)$ & $1-7$ & $4.00 \pm 0.32$ & & \\
\hline & & H.eurysternus & $43(29.05 \%)$ & $1-13$ & $4.74 \pm 0.47$ & & \\
\hline & & Subtotal & $105^{*}(70.94 \%)$ & $1-16$ & $4.07 \pm 0.51$ & & \\
\hline
\end{tabular}

The problem of external parasite seems to be crucial as they are widely distributed in relation to species, sex, age groups, breed and nutritional condition of animals. Tick and lice infestation in cattle has significant economic importance due to direct and indirect loss of production, skin damage, immunosuppression, nuisance and biological vectors of different viruses and protozoa. Ticks of known significance include Boophilus microplus which is the vector of Babesia bigemina, Theileria orientalis and Anaplasma marginale infections in cattle (Soulsby, 1982). Haemaphysalis bispinosa has been responsible for the 
transmission of Babesia to cattle, Babesia gibsoni to dogs and Babesia motasi to sheep. The common dog tick, Rhipicephalus sanguineus is reported to be a vector for Rickettsia conorii, an agent of spotted fever rickettsioses in humans (Raoult and Roux, 1997).

It may conclude that cattle population of the study area highly (56.8\%) infested with ectoparasites. Closer attention should pay towards control measures to prevent economic loss caused by such infestation and transmission of pathogens to domestic animals and humans as well. A better understanding of the diversity and distribution of ectoparasites on domestic animals in study areas can help direct efforts to control these parasites.

\section{REFERENCES}

BBS. 2001. Statistical Pocketbook of Bangladesh. Bureau of statistics (Statistic Division), Ministry of Planning, Government of the Peoples Republic of Bangladesh, Dhaka, Bangladesh.

BER (Bangladesh Economic Review). 2008. Economic adviser's Wing, Finance Division, Ministry of Finance. Government of the People's Republic of Bangladesh, Dhaka, Bangladesh.

Cable, R. M. 1967. An Illustrated Laboratory Manual of Parasitology, $4^{\text {th }}$ edn, Burgress Publishing Co., Minneapolis, Minnesota, USA. pp. 111-131.

Coles, G. C., Hadley, P. J., Milnes, A. S., Green, L. E., Stosic, P. J. and Garnsworthy, P. C. 2000. Relationship between lice infestation and leather damage in cattle. Vet. Record., 153: 255-259.

DLS. 2001. Department of Livestock Services. Ministry of Fishery and Livestock. Government of the People's Republic of Bangladesh, Dhaka, Bangladesh.

Etter, E., Chartier, C., Lefrileux, Y. and Borgid, L. P. 1999. The influence of nutrition on the periparturient rise in fecal egg counts in dairy goats. Revue de Med. Vet., 150: 975-980.

Ghosh, S., Bansal, G. C., Seitzer, U. and Ahmed, J. S. 2007. Status of tick distribution in Bangladesh, India and Pakistan. Parasitol. Res., 2: 207-216.

Gibney, V. J., Campbell, J. B., Boxler, D. J., Clanton, D. C. and Deutscher, G. H. 1985. Effects of various infestation levels of cattle lice (Mallophaga: Trichodectidae and Anoplura: Haematopinidae) on feed efficiency and weight gain of beef heifers. J Econ. Entomol., 78: $1304-1307$.

Islam, M. K., Alim, M. A., Tsuji, N. and Mondal, M. M. H. 2006. An investigation into the distribution, host-preference and population density of Ixodid ticks affecting domestic animals in Bangladesh. Trop. Anim. Health Prod., 38: 485-490.

Jabbar, M. and Green, D. A. G. 1983. The status and potential of livestock within the context of agricultural development policy in Bangladesh, The University of Wales, Aberyswyth, UK, p. 113.

Lloyd, S. 1983. Effect of pregnancy and lactation up on infection. Vet Immunol Immunop., 4: 153-176.

Manan, A., Khan, Z., Ahmad, B. and Abdullah. 2007. Prevalence and identification of ixodid tick genera in frontier region Peshawar. J Agr Biol Sci., 2(1): 21-25. 
Milnes, A. S. and Green, L. E. 1999. Prevalence of lice on dairy cattle in England and the bordering countries of Wales. Res. Vet. Sci., 47: 497-510.

Petney, T. N., Kolonin, G. V., Robbins, R. G. 2007. Southeast Asian ticks (Acari: Ixodida): a historical perspective. Parasitol Res., 101(2): S 201-205.

Radostits, O. M., Gay, C. C., Hinchcliff, K. W. and Constable, P. D. 2007. Veterinary Medicine: A Textbook of Cattle, Sheep, Pigs, Goats and Horses. 10 ${ }^{\text {th }}$ edn., Bailliere Tindall Publishers, UK., pp. 2156.

Raoult, D. and Roux, V. 1997. Rickettsioses as paradigms of new or emerging infectious diseases. CMR., 10: 694-719.

Rony, S. A., Mondal, M. M. H., Begum, N., Islam, M. A. and Affroze, S. 2010. Epidemiology of ectoparasitic infestations in cattle at Bhawal forest area, Gazipur. Bangl J Vet. Med., 8(1): 27-33.

Sanjay, K. and Prasad, K. D. 2004. Prevalence of common ectoparasites infecting cattle and buffaloes in some areas of Jharkhand. Indian J Anim Sci., 74(9): 938-939.

Schlesselman, J. J. 1982. Case Control Studies. Oxford University Press, New York, pp. 174-177.

Soulsby, E. J. I. 1982. Helminths, Arthropod and Protozoa of Domesticated Animals, $7^{\text {th }}$ edn. Bailliere, Tindall and Cassell Ltd. pp. 136-346, 365-491 and 763-778.

Swai, E. S., Karimuribo, E. D., Ogden, N. H., French, N. P., Fitzpatrick, J. L., Bryanto, M. J. 2005. Seroprevalence estimation and risk factors for Anaplasma marginale on small holder dairy farmers in Tanzania. Trop. Anim. Health Prod., 37: 599-610.

Wall, R. and Shearer, D. 1997. Veterinary Entomology, $1^{\text {st }}$ edn, Chapman and Hall, 2-6 Boundary Row, London, pp. 43-135.

Weeks, C. A., Nicol, C. J. and Titchener, R. N. 1995. Effects of the sucking louse (Linognathus vituli) on the grooming behavior of housed calves. Vet. Record., 137: 33-35.

Yacob, H. T., Ataklty, H. and Kumsa, B. 2008. Major ectoparasites of cattle in and around Mekelle, northern Ethiopia. Entomol. Res., 38(2): 126-130. 